Preprint version. Full citation: Gautier, Lara; Karambé, Youssouf; Dossou, Jean-Paul; \& Samb, Oumar Mallé. (2020). Rethinking development interventions through the lens of decoloniality in sub-Saharan Africa: The case of global health, Global Public Health. Published version available at: https://doi.org/10.1080/17441692.2020.1858134

\title{
Rethinking development interventions through the lens of decoloniality in sub-Saharan Africa: the case of global health
}

\begin{abstract}
There has been much talk about decoloniality in global health lately. The approach, which has arisen in various communities around the world, suggests an interesting critique of the Western dominant model of representations. Building upon the 'decolonial thinking' movement from the perspective of Francophone African philosophers, we comment on its potential for inspiring the field of global health development intervention. Using existing literature and personal reflections, we reflect on two widely known illustrations of global health interventions implemented in subSaharan Africa - distribution of contraceptives and dissemination of Ebola virus prevention and treatment devices-featuring different temporal backdrops. We show how these solutions have most often targeted the superficial dimensions of global health problems, sidestepping the structures and mental models that shape the actions and reactions of African populations. Lastly, we question the ways through which the movement of decoloniality might indeed offer a credible positioning for rethinking global health interventions.
\end{abstract}

Keywords: global health, development interventions, decoloniality, sub-Saharan Africa 
Preprint version - Gautier et al., 2020

\section{Background}

In Africa's modern history, all African countries, except Liberia and Ethiopia, have been colonized by European powers. Hereafter in this paper, those formerly colonized countries will be referred to simply as African countries. Ever since their independence from colonial European powers, development aid programs have been rolling out throughout those African countries with mixed levels of success (Easterly, 2006). Despite the large investments in aid programs in developing countries, interventions (e.g., in the field of maternal health) are not yielding the expected outcomes (Ritchie et al., 2016). Some authors even cast doubt on the positive results of some of those programs. They argue, for instance, that some of the positive outcomes of the Millennium Development Goals have been instrumentalized for political purposes (Hickel, 2016; Turshen, 2014). In particular, Hickel (2016) claims that there have been statistical manipulations in relation to malnutrition and poverty alleviation outcomes, and that international organizations have used misleading definitions, thereby leading to gross underestimations.

There are multiple reasons for the mixed outcomes of these aid interventions, ranging from inappropriate technical design to lack of contextual understanding. Critiquing the coloniality of some of these interventions is one way to unpack their limitations, and to rethink the way development aid unfolds. Many countries traditionally involved in designing and financing such development aid initiatives formerly had colonial empires. There has been some discussion in the international sphere as to whether some of those aid programs could represent a sort of extension of the colonial model, reinstating the paternal, hierarchised image of the hand that gives and the hand that receives (Stein et al., 2016; Pai, 2019a). These non-dominant reflections have yet to yield substantial policy changes in global health governance arenas. Some Francophone African philosophers argue that, in former Western colonies, the end of colonialism has not led to the end of "coloniality" (Mbembe \& Sarr, 
2017). In other words, colonial systems of hierarchies, knowledge and culture persist even after political independence (Quijano, 2000). For instance, the response to COVID-19 has been recently described as being shaped by "colonialist patterns that centre Euro-Western knowledge systems" (Büyüm et al., 2020, p. 2).

Global discourse and efforts have promoted the implementation of national ownership for an enhanced efficiency of international aid programs developed by "external development partners." Yet such increased attention to the concepts of ownership and "partners" of development aid might have contributed to overshadow and marginalize questions about the structuring process of intervention approaches unfolding in former colonies of Western empires in the global South. For instance, some authors have showed that speaking of "partners" involves a shift from acknowledging obvious material discrepancies in development assistance, to focusing on "equal partnerships" (Gautier et al., 2018; Ouattara \& Ridde, 2013). In global health, such a shift means buying into a culture of pretense that intentionally or unintentionally "unknows" anything that might erode this idea of equality, including widespread material inequalities, the legacy of paternalistic international health and the local memories of colonialist medicine (Crane, 2010; Geissler, 2013). Looking into these elements is precisely what is needed before proceeding to the design of any sensible global health intervention.

Decolonial thinkers ${ }^{1}$ (Mbembe \& Sarr, 2017) call for a reconsideration of how development interventions are produced in Africa. The issue is to discuss the "coloniality" of aid programs by interrogating their Western-centric roots. Focusing specifically on global health aid initiatives, this article offers a critical reflection on two main areas of intervention

\footnotetext{
${ }^{1}$ This article uses a "decolonial" approach rather than a "postcolonial" approach; in French literature, "postcolonial" studies may also carry Marxist ideology in the context of social class struggles of thirdgeneration immigrants in France (e.g., Bancel, 2012).
} 
Preprint version - Gautier et al., 2020

within the African continent. Our research questions are as follows: How do global health interventions reflect colonial ways of thinking? To what extent does the movement of decoloniality offer a credible standpoint for rethinking global health interventions?

Using existing global public health literature and our own interdisciplinary reflections (our authorship features the fields of public health, anthropology, sociology, and public policy), we have taken interest in unpacking specific global health responses through two interventions. We analyze recent interventions aiming to contain Ebola virus disease (EVD) outbreaks, e.g., the setup of temporary Ebola treatment centres in response to EVD outbreaks, and interventions aiming to extend family planning practices, e.g. the distribution of contraceptive methods. These two cases feature different temporal backdrops: the first plays out over the short term given the urgency of the situation; and the second is a long-term intervention. As a first step, we describe decolonial thinking from the perspective of Francophone African thinkers. Next, we explore how the iceberg metaphor can be used to reveal how mental models mismatch in development aid. Third, we apply the iceberg metaphor to unpack the coloniality of the two aforementioned global health interventions: EVD-response and family planning interventions. Finally, we reflect on the ways decoloniality may be used to rethink global health interventions.

\section{Challenging the coloniality of practice and knowledge}

Different from colonization-a political and historical process-the concept of coloniality refers to the results of that process, including its social constructions, practices, hierarchies, and violence. According to several Francophone African thinkers, decolonization did not bring the end of coloniality in African countries; and, in response, these authors suggest engaging in “decolonizing knowledge and practice” (Mbembe \& Sarr, 2017). In this section, we explain the foundation of this movement. 
Preprint version - Gautier et al., 2020

Since the end of the Second World War, we have witnessed the growing voice of socalled "primitive" peoples (Hountondji, 2007, p. 2) calling for decoloniality. At the global level, decolonial thinking primarily draws from South-American and Caribbean philosophers (e.g., Ramón Grosfoguel, Anibal Quijano, Walter Mignolo, Catherine Walsh) who, by contesting Eurocentric and American schools of thought, developed critical analytical frameworks, such as the modernity/coloniality/colonial matrix of power (Jivraj et al., 2020).

While embracing this heritage, the decolonial thinking movement in Francophone Africa is primarily rooted in the "Africana" philosophy (e.g., Frantz Fanon, Cheikh Anta Diop, Ngugi wa Thiong'o), based on the deconstruction of "universal" Western knowledge and intervention models in postcolonial Africa (Abadie, 2019). This approach is anchored in the objection to the Western appropriation of "universality." In their seminal book Écrire l'Afrique-Monde, Achille Mbembe (a Cameroonian philosopher, professor at the University of the Witwatersrand in South Africa) and Felwine Sarr (a Senegalese economist and writer, professor at Duke University in the United States) offer a coherent collection of chapters written by diverse French-speaking African decolonial thinkers. They offer multidisciplinary perspectives on the how the African continent can become a source of inspiration for the world. In this book, Africana philosopher Nadia Yala Kisukidi asserts that philosophical criticism unmasked a deceiving universalism. Kisukidi demonstrates that Western philosophy has a body, a color and a location (Kisukidi, 2017, p. 54). According to decolonial thinker Souleymane Bachir Diagne, universalism must be removed from the Western world. One could connect Diagne's argument to Grosfoguel's concept of "pluriversalism” (Grosfoguel, 2012). The adoption of this concept would enable to move away from "Western universalisms" (Affun-Adegbulu \& Adegbulu, 2020).

Such positionality bears multiple implications for the production of a decolonized knowledge that would also reflect the "pluriversal" nature of the world. Kisukidi suggests a 
Preprint version - Gautier et al., 2020

state of decoloniality achieved through the shaping of a world that — despite the cunning nature of coloniality — does not rest upon colonial difference, and through the adoption of a strategic interpretation of the past from a desirable future (Kisukidi, 2017, p. 65). Such desirable future would lead to the development of Africa. But how would this development take shape? Is it simply a question of moving away from Western models of development and modernity that have led their pioneers to act as "guardians," exerting domination that continues to this day (Diagne, 2017, p. 74), in favor of a romanticized approach focused on communality, family and community (Abadie, 2017, p. 4)? Sarr proposes a critical rethinking of therapeutic and technical knowledge, questioning the universality of scientific methodology in favor of African analysis categories (Sarr, 2017, p. 374). In terms of global health interventions, this reflection could lead to significant changes in the ways they are designed and implemented.

That said, decolonial thinkers acknowledge that Africa has also adapted to these development models, scientific approaches and Western categories. Kisukidi herself admits a certain "undecolonizability," and Diagne acknowledges the limitations of the systematic denial of Western knowledge based on them being the product of a different historical path and carrying certain problematic assumptions (Abadie, 2017, p. 5 quoting Diagne, 2017). On the contrary, the pathway would be to appropriate such knowledge while highlighting African interpretations.

\section{The iceberg metaphor applied to global health}

How did we come to read about the need to challenge the persisting coloniality of aid programs? Over the course of our respective careers, and before becoming scholars, we witnessed the limitations associated with the ways many global health interventions were designed and implemented in African countries (Pai, 2019b). We observed, for instance, a 
Preprint version - Gautier et al., 2020

lack of consideration for basic contextual features that would likely impede implementation, e.g. lack of electricity or running water, and the widespread conservative beliefs restricting women's choice. We also observed failure to anticipate the potential reawakening of memories from a not-so-distant colonial past. These observations led us to formulate the following simple question: given that for the most part these interventions emerged in or were funded by Western countries, might this very characteristic explain the unfitness or failure of some of those interventions in African countries? We searched the literature for tools or guidelines that might help us understand such potential discrepancy. We found that a useful way to unpack global health interventions in this context would be to apply the iceberg metaphor as developed by Sweeney and Meadows (2010).

\section{The iceberg metaphor}

The iceberg metaphor (Figure 1) is a systems thinking pattern founded on the idea that problems are made up of an explicit (or visible) component as well as an implicit underlying component. As in an iceberg, the underlying component makes up approximately $90 \%$ of the total mass.

[Figure 1 about here]

This model offers a four-tiered analysis approach to grasp to the fullest extent possible a problem, its determinants and its relationships with other surrounding elements (Sweeney \& Meadows, 2010). The first level involves the visible events that are observed. It comprises the most explicit and apparent symptoms and signs of a problem. The second level, located directly below the previous level in terms of spatial representation, holds patterns showing recurring associations between various observed events. The third level, below the second, is made up of systems structures such as physical objects, organizations, laws, policies or rituals which shape trends. The fourth and deepest level is comprised of mental models, defined herein as sets of attitudes, beliefs and perceptions regarding what is moral and what is not, 
Preprint version - Gautier et al., 2020

values, and any component born from internalized collective social representations of the surrounding world and the relationships between its various parts. The persistence of structures is the result of mental models.

\section{A Western colonial mental model?}

We found that the deepest analytical tier, that of mental models, was the most informative for unpacking global health interventions. It helped us identify two categories of mental models that could be at the origins of the potential mismatch explained above: the colonial mental model and the African population's mental models. We conceived the colonial mental model as a set of internalized ideas, values, attitudes, perceptions, and beliefs rooted in colonial logic, that grounds systems of hierarchies, knowledge and culture, in this particular case, between the West and its former colonies in modern history. Some aspects of this Western coloniality include, for instance, Western-centrism, paternalism, "Western" system rationality and scientific criteria, and the value assigned to governance and accountability (Mignolo, 2007; Kohn \& Reddy, 2017).

\section{Which mental models for African populations?}

The populations of Africa are diverse, as are the mental models underlying the events observed within them. While we recognize these variations, we use the expression "mental models of African populations" to refer to the common elements of the systems of representation, attitudes, values and beliefs shared by the diverse peoples of Africa. Such elements can be referred to as uniform in the sense that they are all different from the Western colonial mental model outlined above. In fact, the shared experience of colonization and its ensuing traumas have contributed to shape such commonalities and similarities between these "African" mental models. We have reported on several subsets pertaining to the plural 
Preprint version - Gautier et al., 2020

identity of African peoples (N'Goulakia, 2015), including precolonial sociopolitical models and their remnants (the foundation of human relationships, relationships with the gods and spirits, endogenous or traditional religions such as Vodun, relationships with the embodiment of power, economic models, etc.), the foundations of cultural expression systems (metaphoric representations, language-based beliefs, taxonomy, relationships, etc.) and the foundations of environmental relationships (with earth, water, forests, animals, etc.) (Diop, 1955; Garuba, 2013). This is a non-comprehensive list and the initial categorization is subject to change. These mental models or the remnants thereof coexist with mental models introduced through colonization.

Decolonial thinkers argue that the models which reflect the plurality of the African populations as separate from Western or colonial mental models. And yet this distinction is not so easily made. In our globalized world, "African" mental models and "Western" mental models stand as diametric opposites on a large spectrum which steers the development of analysis categories (or frameworks) as well as human action. At the centre of this spectrum of mental models transpire dynamic transformations resulting from a show of force between diametric categories. We have decided to focus on the outermost categories, which are further removed from ambiguities, to better reflect the contrasts and best illustrate our line of argument.

\section{“Colonialized" aid programs: the case of global health}

The health care sector is particularly effective for illustrating the coloniality at work in aid programs. In fact, the nature itself of colonial tropical medicine was paternalistic, patriarchal and geared toward colonial conquest practices and the exploitation of settlements (Birn et al., 2017; Ouédraogo et al., 2019). Few and far between were any humanitarian ideas or public health goals in the full sense of the terms. The global health model that can be seen today 
Preprint version - Gautier et al., 2020

tends to perpetuate unequal donor-beneficiary relationships (inherited from international health practices from the 1970s to 1990s) and "inclusive" global health partnership narratives which struggle to materialize in the real world (Gautier et al., 2018). The transition is therefore imperfect, with changes occurring within superficial analytical levels, without a meaningful reassessment of the underlying mental models. Even in modern days of development aid, many argue that paternalism remains (e.g., Oloruntoba, 2020; Pai 2019a), and colonial conquest and exploitation goals sometimes give way to commensurable market conquest and resource-oriented exploitation goals. For instance, there are multiple commercial battles unfolding between the various countries operating on African soil (European countries as well as China, India and Turkey, for instance) (Aurégan, 2019). Namely, the operation of foreign mining companies on African soil is not without public health repercussions for African people (Campbell, 2009).

\section{A disconnect between global health mental models?}

In this section, we apply the iceberg metaphor to unpack two wide-known global health interventions: the EVD outbreak response and family planning (boxes 1 and 2). We chose these two interventions because of the inherent complexities associated with their design and implementation, given the contexts in which they were delivered. We also chose them because they represent salient illustrations of a mismatch between the colonial mental model and African populations' mental models, which might offer a potential explanation for their mixed outcomes (boxes 1 and 2).

\footnotetext{
Box 1. Interventions to prevent and control EVD outbreaks in West Africa

In 2014, based on past EVD outbreaks in other parts of sub-Saharan Africa, international organizations, non-governmental organizations (NGOs) and national public authorities designed and implemented a wide range of individual- and community-level interventions to
} 
prevent and control the disease in Guinea, Liberia and Sierra Leone, as well as neighboring countries. These included the construction of temporary Ebola treatment centres, the spread of radio spots announcing prevention messages, the ban of all contact with the ill admitted into Ebola treatment centres, the ban on hunting and consuming bushmeat, the closing of borders, and the immediate disposal of the bodies of deceased EVD patients. These interventions brought several issues related to acceptability and implementation, including widespread fear which hindered health-seeking behaviors (Ansumana et al., 2017). As a result, in addition to its heavy death toll, the EVD outbreak in West Africa cast a tremendous social and economic burden (Huber et al., 2018). Perhaps even more problematic, the lack of social acceptability of some of the interventions led some of the most affected communities to not only question the legitimacy of public health system's infrastructures but also, in certain instances, to engage in violent attacks against healthcare workers. This shortcoming generated long-term consequences such as a breakdown of trust in health systems and dramatic reductions in healthcare utilization, especially among women and children (Elston et al., 2017).

\section{Box 2. Family planning interventions in sub-Saharan Africa}

International organizations and NGOs have been introducing family planning interventions in many parts of sub-Saharan Africa for at least 40 years, the aim being to support national efforts to control population dynamics and reduce the burden of unintended pregnancies. Such interventions primarily include the dissemination of large-scale awareness campaigns about the benefits of family planning and the widespread distribution of contraceptive pills. The lack of anticipation of implementation challenges (e.g., creating parallel distribution systems that fail to integrate into existing structures) and social acceptability (e.g., memories of colonization as well as representations of fertility - see also below) has, according to experts, 
Preprint version - Gautier et al., 2020

created the conditions for producing mixed outcomes (Aliyu, 2018; May, 2017). Thus, despite massive foreign aid, and despite the fact that family planning aid to countries in sub-Saharan Africa is $48 \%$ higher than aid to countries outside of the region (Asiedu, 2013), there are still a low prevalence of contraceptive use (15\% in West African countries) and persisting high rates of unintended pregnancies (i.e., 33.9\% in sub-Saharan Africa) (Bain et al., 2020; Cleland et al., 2011). An estimated one fourth of women who had unintended pregnancies resort to unsafe abortion. These outcomes have multiple adverse health, economic, and societal consequences (Bain et al., 2020).

\section{Technofix interventions that ignore the mental structures and models of African societies}

The 2014-2015 EVD outbreak in West Africa and the introduction of modern family planning in sub-Saharan societies have spurred the diffusion of interventions on the African continent (e.g., the construction of temporary EVD treatment centers and the distribution of modern contraceptives). These interventions represent the concept of "technofix". Technofix solutions refer to a category of quick and effective solutions that a great number of global health aid stakeholders - most based in the West—have been committed to producing (Lock \& Nguyen, 2018). Inspired by the world of biotechnologies (such as pentavalent vaccines for children), technofix thinking can be applied to a wider scope of solutions involving rapid-response emergency interventions. Such thinking relates to the superficial layer of the iceberg metaphor-a quick response to complex problems that fails to acknowledge the deeper layers of the iceberg. In addition, Africana thinkers would characterize these technofix biotechnologies as features of Western systems of representations and scientific methods that reflect the Western colonial model. Considering the acceptability and implementation challenges that these interventions faced, and the resulting mixed outcomes (boxes 1 and 2), 
Preprint version - Gautier et al., 2020

we contend that family planning interventions and efforts to contain EVD outbreaks should go beyond such technofix solutions that might be rooted in sociocultural contexts tainted by coloniality.

The setup of temporary EVD treatment centers by external actors-international NGOs-perpetuated the idea that the disease had foreign origins. Seeing clinicians wearing what looked like "spacesuits" only added to this assumption (WHO, 2015). The physical dimension of those foreign EVD response interventions, thus greatly contributed to fuel communities' suspicion.

As for family planning, the development of modern contraceptive methods is rooted in the Western mental model, which mainly considers "giving birth" as a biomedical process that can be safely controlled by humans. This perspective clashes with several African populations' mental models, which consider that "giving life" is mainly mediated by immaterial entities or spirits (May, 2017; Vigan et al., 2020). In African mental models, spirits are considered more powerful than humans; for this reason, several African communities judge that it is not up to human beings to interfere with the spiritual processes associated with "giving birth" (Vigan et al., 2020).

The content of these interventions and the way in which they are (or were) deployed and assessed reveal not only a contextual disconnect, but also the difficulty to break away from the coloniality-infused mental models in which the approaches are rooted (see also below). This leaves little room to devise local solutions based on the local mental models surrounding the issue. This disconnect between coloniality-based interventions and the mental models at play where the interventions are being staged is the source of several potential challenges; the inadequate design of interventions attributable to a lack of consideration of key features of underdocumented local mental models leads to weak ownership, poor implementation, or rejection of interventions. Part of the challenges experienced in the 
Preprint version - Gautier et al., 2020

management of the EVD outbreak crisis may be due to this disconnect (Richardson et al., 2019).

\section{The populations' mistrust toward health care interventions}

Over the long term, the disconnect between these mental models nourishes a feeling of mistrust toward external aid programs, including health programs.

Many of the EVD containment measures greatly contributed to deepening the mistrust toward foreign stakeholders involved in "aiding" the impacted African communities. We mentioned earlier the radio spots and messages broadcasted by health professionals from international NGOs working onsite: this strategy contributed to the spread of fear and uncertainty within the affected communities. In some communities, these strategies led to the onset of violent behavior toward such outsiders (Liu, 2015). In addition, the silence hovering over EVD prevention and control measures (What was happening to the ill? Where were the bodies of the deceased being taken?) led to a large portion of the population feeling shut out, thus opening the door to a slew of interpretations and to the spread of rumors.

As for family planning interventions, decades of social marketing of the "pill" (since the 1980s in Mali, for instance), spearheaded by international partners (Western NGOs for the most part), have marked the collective memory. Today, social conceptions surrounding contraceptives include the idea of biomedical products brought from the West to prevent Africans from multiplying (Coulibaly, 2017, p. 229). This belief-deeply rooted in the collective imagination of African populations_-stems from the colonial period when a significant statistical system was rolled out to control colonized peoples. Such interpretations could have been exacerbated by the memory of decades of (sometimes fatal) medicinal experimentation in African countries during colonial times (Lachenal, 2014). This collective memory might also explain African women's fear of contraceptives' side-effects (Hindin et al., 2014). Those potential side-effects reflect another possible mismatch between mental 
Preprint version - Gautier et al., 2020

models. Some modern contraceptives lead to changes in menses patterns including irregular, infrequent menses, and/or longer or shorter bleeding (WHO and Johns Hopkins Bloomberg School of Public Health, 2018). In the Western mental model, these changes in menses patterns are considered normal and not harmful (WHO and Johns Hopkins Bloomberg School of Public Health, 2018). However, in African populations' mental models (such as in Southern Benin), changes in menses patterns have social implications. Indeed, during menses, women are considered temporarily "unclean”, which generates temporary forms of social exclusion. For women, changes in menses patterns involves a reduced control over when to perceive oneself, or be perceived by others, as clean or unclean. This may lead to longer social exclusion and possible severe social consequences (Vigan et al., 2020). Grounded on Western, biomedical mental models, global family planning policies do not address such kind of consequences.

\section{Intrinsically irrational?}

Liu (2015) reports on the experiences of employees of the NGO Doctors Without Borders responding to the EVD outbreak in Forécariah (Guinea), who were in contact with members of the community. In the middle of the outbreak, some members of the community still expressed a certain skepticism regarding the reality of EVD and were spreading "rumors" about the presence of strangers dressed in space suits spreading the disease. On this basis, Westerners (including decision makers, global health practitioners and researchers) described hard-hit African populations as "unreasonable" because of the "irrational" discourse adopted following the preventative injunctions issued to halt the spread of EVD. That said, the protective suits used against the virus were actually quite impressive and could understandably promote the perception that the disease came from somewhere else, somewhere far away. Furthermore, the restrictions enforced by national and international authorities regarding the emergency (e.g., order to stay away from the body of the deceased) 
Preprint version - Gautier et al., 2020

only reinforced the sense of moral and political violence against communities (Gautier et al., 2017; Richardson et al., 2019). This sense of moral and political violence was heightened by the occasional presence of foreign military on Liberian soil, for instance (Hofman \& $\mathrm{Au}$, 2017).

Overall, these unfortunate EVD experiences shine light on the colonial legacy that is well entrenched in the collective memory of the communities of West Africa. This legacy is shaped by cycles of widespread infectious disease prevention and treatment initiatives which often result in high levels of trauma for the colonized peoples (Lachenal, 2014). We can therefore not dismiss the idea that each new outbreak in this area of the world brings to surface colonial phantoms along with their violence and symbols. By failing to acknowledge the lingering violence experienced to this day by populations hit by outbreaks, the West further strengthens the sense of denial of suffering. Also, by casting a veil of discredit over the representations of affected communities, branding them one by one as "conspiracy theories," rumors and misinformation, without trying to decipher them or identify the underlying rationales, we are silencing the suffering. The lack of importance attributed to these discourses also contributes to deepening this sense of denial and lack of recognition within the globalized world. Indeed, the globalized world does tend to validate, promote and prioritize "rational" Western mental models.

\section{Counter-Discourse as Decolonizing}

These examples of distrust lead one to acknowledge that the non-Western mental models in these communities should be given a louder voice. We must develop a more systematic approach for exploring, defining, describing and dynamically analyzing them. An interesting example of how African mental models might gain visibility and be accounted for is the Saga Santé Facebook page. Since February 2016, the Saga Santé project, which is geared toward an enhanced and ongoing attentiveness to the voices of African populations, uses Facebook to 
create a continuous and interactive sharing space between public health stakeholders and African youth regarding various health-related issues ${ }^{2}$. The Facebook page is facilitated by a team of Francophone African public health medical doctors trained to value multiple forms of knowledge. This facilitation approach encourages members to openly voice their thoughts, ideas and interpretations about a given issue on the platform. Consequently, a different language has emerged through this uncensored space. Participants express themselves more freely about organizations such as the World Health Organization and its role in various outbreaks and the EVD outbreak in particular. Ultimately, the goal is to use this counterdiscourse to better understand and decipher the logic at work in the groups using these platforms in order to develop and implement durable, more context-informed, and therefore more acceptable, interventions.

Counter-discourse also emerges in family planning interventions. For instance, Coulibaly (2017) speaks of the "multirationality" of family planning perceptions in Mali. On the one hand, Coulibaly mentions that health care professionals have adopted "Western" discourses founded on social (empowerment of women), health-related and economic grounds (impact of birth spacing on household savings and community development). These discourses have been taken directly from international stakeholders (NGOs, lenders, etc.) and, as such, feature a rationale based on Western mental models. On the other hand, as the author analyzes the ways lay persons think, he identifies precepts of religious morals and traditional values (promoting a critical stance toward contraceptives as "children are a gift from God") which encourage fertility (Coulibaly, 2017). These precepts stand in stark contrast with what one might call a more "pragmatic"—or "rational"—perception of men and women experiencing their sexuality in and out of marriage, using contraceptives out of convenience

\footnotetext{
${ }^{2}$ Saga Santé Facebook page: https://fr-fr.facebook.com/sagasante/. As of August 2020, it has over 27,500 followers spread over several Francophone African countries.
} 
Preprint version - Gautier et al., 2020

(for a man and his mistress) and as a result of fatigue following repeated pregnancies (for married women) (Coulibaly, 2017).

However, the West does not hold all the blame. In fact, African decision makers sometimes become complicit in projecting Western interpretations over such complex issues. While several African countries are heavily dominated by deeply rooted technical and financial partners, and while coercion can come into play, many political leaders maintain a strong level of autonomy with respect to Western impositions (e.g., see Wireko \& Béland, 2017). The relationships between African decision makers and international partners often subsume a complex interplay of trust/proximity (often arising out of the training institutions attended by the former) and expedience (for both the former and the latter) (Whitfield, 2008). To sum up, African policy actors do wield significant latitude to make their own decisions. However, in many instances, they too project Western mental models within their own contexts.

\section{Applying decoloniality in global health interventions}

In this last section, we suggest ways through which decolonial thinking could help a) design global health interventions while accounting for prospective social acceptability (Sekhon et al., 2017), and b) deliver such interventions while being mindful of the contexts and structures at play.

Engaging in decolonial thinking using the iceberg metaphor pushes us to acknowledge the above-mentioned multirationality. Recognizing such multirationality could become an interesting beacon for redefining development aid and global health interventions in particular. Recognizing such multirationality also enables to move away from idealizing African mental models (or the mental models of vulnerable groups) or depicting them as "more human" or "more just" through romantic portrayals. These man-made models have strengths and weaknesses that need simply be recognized. In particular, communities affected 
Preprint version - Gautier et al., 2020

or targeted by global health interventions have a right to self-determination, dignity, respect and effective, meaningful involvement in addressing their challenges on their own terms (whether it involves African solutions or not). This concern constitutes a fundamental condition for sustainable development (Samb et al., 2013). Without such effective and meaningful involvement, any development intervention risks being reduced to a superficial, highly vulnerable workaround - failing to acknowledge the deeper layers of the iceberg. In addition, when it comes to health, one cannot ignore the advances of modern medicine in providing technical solutions that can effectively contribute to outbreak management, for instance. Requests for quality health care services made by African populations cannot go unanswered as such populations are sometimes deceived or let down by traditional medicine.

Rather than categorically rejecting Western mental models-which, as mentioned above, focus on technofixes - we must work to ensure their proper integration by finding local supports that are well adapted to African systems of representation. The preferred route would therefore be to rethink the approaches and techniques that are used in such a way as to incorporate the local knowledge and collective imagination of the targeted communities while engaging them in a balanced, decolonialized dialogue. The successful combination —or hybridization — of the Western and African mental models to design new global health interventions would be an opportunity to increase the relevance of such interventions and, above all, their acceptability within the targeted communities (Cleaver et al., 2016).

Decolonial thinking can also help prepare for the delivery of global health interventions. Significant tangible and intangible resources, along with sometimes exorbitant human resource expenses, are invested in global health interventions that are all too often poorly implemented (Sarriot et al., 2004). Such interventions tackle issues that in and of themselves are fixable, but that persist over time with worrisome morbidity and mortality rates in which vulnerable populations are greatly overrepresented. Persistent health 
Preprint version - Gautier et al., 2020

inequalities across countries and within countries are largely attributable to poor implementation and/or lack of consideration for context-specific, structural determinants (Craig et al., 2018; Ritchie et al., 2016). Through the promotion of technological innovations, the global health interventions detailed above focus on the "discovery" aspect of the problem, rather than the "delivery" aspect (Abimbola, 2018). Such focus precluded thinking about how to make the interventions work in practice, given the contexts at hand. Critically, the delivery aspect emphasizes the central role of implementation, including the inner and outer contexts

of the intervention being implemented. Engaging in decolonial thinking by highlighting issues of power and social hierarchies, as well as the cultural norms at play, would enable to anticipate implementation barriers.

The prospective assessment of social acceptability when designing global health interventions would thus ensure a stronger emphasis on the needs of local populations and the power structures at hand. However, a meaningful engagement in decolonial thinking would require a profound and long-term transformation of foreign aid practices. As highlighted above, designers and implementers of such interventions should indeed primarily make sure to a) ask uncomfortable questions about the relevance of introducing yet another intervention, b) unpack the mental models at hand, c) recognize multiple rationalities and d) understand, value and embrace local norms and structures. Ultimately, this type of approach could achieve a better integration of global health interventions into African communities.

\section{Conclusion}

To answer our initial question, we have pursued an interdisciplinary approach (thus breaching disciplinary silos) bridging anthropology, sociology, public policy and public health. We have supported our arguments with two telling examples: interventions aimed at containing EVD outbreaks and interventions directed toward the expansion of family planning in Africa. This 
Preprint version - Gautier et al., 2020

article argues that relatively recent impediments to these interventions can be explained by the complacency exhibited with regard to Western-centric solutions. Such solutions are characterized by a distinct lack of consideration for the underlying structures and mental models of African societies during the production of interventions.

Although imperfect, decolonial thinking could serve as a baseline for the critical analysis of the relevance, design and implementation of interventions in African countries. Above all, its goal is to make us question the need for intervention. The next step, no matter our place of origin, would be to humbly acknowledge the limits of our knowledge with regard to the intricacies of the societies where intervention seems necessary, and to maintain such humility throughout interactions with local partners and beneficiaries. Finally, this process has brought us to step away from Western-centric "universal" scientific rationality in favor of Grosfoguel's concept of “pluriversalism” which acknowledges other forms of knowledge.

\section{References}

Abadie, D. (2017). Depuis l'Afrique, à l'adresse du monde. Recension d'Écrire l'Afriquemonde. Institut de Recherche et d'Enseignement sur la Paix, Thinking Africa. https://papyrus.bib.umontreal.ca/xmlui/bitstream/handle/1866/18994/ndl-ecrire-afriquemonde.pdf? sequence $=1$

Abadie, D. (2019). Introduction : routes, détours et relecture postcoloniale de la philosophie africaine. Philosophiques, 46(2), 279-298.

Abimbola, S. (2018). On the meaning of global health and the role of global health journals. International Health, 10(2), 63-65.

Affun-Adegbulu, C., \& Adegbulu, O. (2020). Decolonising global (public) health: from western universalism to global pluriversalities. BMJ Global Health, 5(8), e002947. http://dx.doi.org/10.1136/bmjgh-2020-002947 
Preprint version - Gautier et al., 2020

Aliyu, A. A. (2018). Family planning services in Africa: The successes and challenges. Family Planning, 69.

Ansumana, R., Keitell, S., Roberts, G. M., Ntoumi, F., Petersen, E., Ippolito, G., \& Zumla, A. (2017). Impact of infectious disease epidemics on tuberculosis diagnostic, management, and prevention services: experiences and lessons from the 2014-2015 Ebola virus disease outbreak in West Africa. International Journal of Infectious Diseases, 56, 101-104.

Asiedu, E., Nanivazo, M., \& Nkusu, M. (2013). Determinants of foreign aid in family planning: How relevant is the Mexico City Policy? (No. 2013/118). WIDER working paper.

Aurégan, X. (2019). L'Inde en Afrique ou l'impossible rattrapage vis-à-vis de la Chine. L'Espace Politique. Revue en ligne de géographie politique et de géopolitique, 36(3).

Bain, L. E., Zweekhorst, M. B., \& de Cock Buning, T. (2020). Prevalence and determinants of unintended pregnancy in sub-saharan Africa: a systematic review. African Journal of Reproductive Health, 24(2), 187-205.

Bancel, N. (2012). Que faire des postcolonial studies : Vertus et déraisons de l'accueil critique des postcolonial studies en France. Vingtième Siècle. Revue d'histoire, 115(3), 129-147.

Birn, A.-E., Pilley, Y., \& Holtz, T.H. (2017) Textbook of Global Health. Fourth Edition. New York: Oxford University Press.

Büyüm, A.M., Kenney, C., Koris, A., Mkumba, L., \& Raveendran, Y. (2020) Decolonising global health: if not now, when? BMJ Global Health, 5:e03394. http://dx.doi.org/10.1136/bmjgh-2020-003394

Campbell, B. (Ed.). (2009). Mining in Africa: Regulation and development. Ottawa: Pluto Press, International Development Research Centre.

Cleaver, S. R., Carvajal, J. K., \& Sheppard, P. S. (2016). L'humilité culturelle: Une façon de penser pour orienter la pratique à l'échelle mondiale. Physiotherapie Canada, 68(1), 2-4. 
Preprint version - Gautier et al., 2020

Cleland, J. G., Ndugwa, R. P., \& Zulu, E. M. (2011). Family planning in sub-Saharan Africa: Progress or stagnation? Bulletin of the World Health Organization, 89, 137-143.

Coulibaly, A. (2017). Multi rationalités et pratiques d'acteurs dans le domaine de la planification familiale au Mali. Anthropologie et Sociétés, 41(2), 223-240.

Craig, P., Di Ruggiero, E., Frohlich, K. L., Mykhalovskiy, E., White, M., Campbell, R., Cummins, S., Edwards, N., Hunt, K., Kee, F., \& Loppie, C. (2018). Taking account of context in population health intervention research: guidance for producers, users and funders of research. Canadian Institutes of Health Research (CIHR)-National Institute for Health Research (NIHR) Context Guidance Authors Group. Southampton: National Institute for Health Research. https://doi.org/10.3310/cihr-nihr-01

Crane, J. T. (2010). Unequal 'partners'. AIDS, academia, and the rise of global health. BEHEMOTH-A Journal on Civilisation, 3(3), 78-97.

Diagne, S. B. (2017). Pour un universel vraiment universel. In A. Mbembé \& F. Sarr (Eds.), Écrire l'Afrique-Monde (pp. 71-78). Dakar: Philippe Rey/Jimsaan.

Diop, C. A. (1955). Nations nègres et culture. Paris: Présences africaines.

Easterly, W. (2006). The white man's burden: why the West's efforts to aid the rest have done so much ill and so little good. New York: The Penguin Press.

Elston, J. W. T., Cartwright, C., Ndumbi, P., \& Wright, J. (2017). The health impact of the 2014-15 Ebola outbreak. Public Health, 143, 60-70.

Garuba, H. (2013). On animism, modernity/colonialism, and the African order of knowledge: Provisional reflections. Contested Ecologies: Dialogues in the South on Nature and knowledge, 42-51. 
Preprint version - Gautier et al., 2020

Gautier, L., Houngbedji, K. A., Uwamaliya, J., \& Coffee, M. (2017). Use of a community-led prevention strategy to enhance behavioral changes towards Ebola virus disease prevention: a qualitative case study in Western Côte d'Ivoire. Global health research and policy, 2(1), 35.

Gautier, L., Sieleunou, I., \& Kalolo, A. (2018). Deconstructing the notion of "global health research partnerships" across Northern and African contexts. BMC medical ethics, 19(1), 49.

Geissler, P. W. (2013). Public secrets in public health: Knowing not to know while making scientific knowledge. American Ethnologist, 40(1), 13-34.

Grosfoguel, R. (2012). Decolonizing western uni-versalisms: decolonial pluri-versalism from Aimé Césaire to the Zapatistas. Transmodernity: Journal of Peripheral Cultural Production of the Luso-Hispanic World, 1(3).

Hickel, J. (2016). The true extent of global poverty and hunger: questioning the good news narrative of the Millennium Development Goals. Third World Quarterly, 37(5), 749-767.

Hindin, M.J., McGough, L.J., \& Adanu, R.M. (2014). Misperceptions, misinformation and myths about modern contraceptive use in Ghana. Journal of Family Planning and Reproductive Health Care, 40, 30-35.

Hofman, M., \& Au, S. (Eds.). (2017). The politics of fear: Médecins sans Frontières and the West African Ebola epidemic. New York: Oxford University Press.

Hountondji, P. J. (2007). La rationalité, une ou plurielle?. Dakar: African Books Collective, CODESRIA-UNESCO.

Huber, C., Finelli, L., \& Stevens, W. (2018). The economic and social burden of the 2014 Ebola outbreak in West Africa. The Journal of Infectious Diseases, 218(Supplement_5), S698-S704.

Jivraj, S., Bakshi, S., \& Posocco, S. (2020). Decolonial Trajectories: Praxes and Challenges. Interventions, 22:4, 451-463. 
Preprint version - Gautier et al., 2020

Kisukidi, N. Y. (2017). Laetitia Africana. Philosophie, décolonisation et mélancolie. In A. Mbembe \& F. Sarr (Eds.), Écrire l'Afrique-Monde (pp. 51-69). Dakar: Philippe Rey/Jimsaan.

Kohn, M., \& Reddy, K. (2017). “Colonialism”. In E. N. Zalta (Ed.), The Stanford Encyclopedia of Philosophy (Fall 2017 ed.). Stanford CA: Stanford University. https://plato.stanford.edu/archives/fall2017/entries/colonialism/

Lachenal, G. (2014). Le médicament qui devait sauver l'Afrique: un scandale pharmaceutique aux colonies. Paris: La Découverte.

Liu, J. (2015). Attention : la lutte contre Ebola n'est pas finie. Actualités Médecins Sans Frontières. https://www.msf.fr/actualites/attention-la-lutte-contre-ebola-n-est-pas-finie

Lock, M., \& Nguyen, V. K. (2018). An anthropology of biomedicine (2 ${ }^{\text {nd }}$ ed.). John Wiley \& Sons.

May, J.F. (2017), The Politics of Family Planning Policies and Programs in sub-Saharan Africa. Population and Development Review, 43: 308-329.

Mbembe, A., \& Sarr, F. (2017). Écrire l'Afrique-Monde. Dakar: Philippe Rey/Jimsaan.

Mignolo, W. D. (2007). Introduction. Coloniality of power and de-colonial thinking. Cultural Studies, 21:2-3, 155-167.

N'Goulakia, L-P. (2015). Afrique subsaharienne: une identité plurielle, un destin commun. Geoeconomie, 1, 59-72.

Oloruntoba, S.O. (2020). The Politics of Paternalism and Implications of Global Governance on Africa: A Critique of the Sustainable Development Goals. In: S. O. Oloruntoba (Ed.), Pan Africanism, Regional Integration and Development in Africa (pp. 165-179). London: Palgrave Macmillan.

Ouattara, F., \& Ridde, V. (2013). Expériences connues, vécues... mais rarement écrites: à propos des relations de partenariat Nord-Sud. Nouvelles pratiques sociales, 25(2), 231-246. 
Preprint version - Gautier et al., 2020

Ouédraogo, S., Gautier, L., Mac-Seing, M., Tine, S., Perez, M. C., Kadio, K., Chegno, R., \& Jones, C. M. (2019). De-patriarchalising and levelling science for French-speaking women. The Lancet, 393(10171), e23-e24.

Pai, M. (2019a). Global health research needs more than a makeover. Forbes. https://www.forbes.com/sites/madhukarpai/2019/11/10/global-health-research-needs-morethan-a-makeover/?sh=683862287e 34

Pai, M. (2019b). Archives of Failures in Global Health. Nature Research Microbiology Community. http://naturemicrobiologycommunity.nature.com/posts/51659-archive-offailures-in-global-health

Quijano, A. (2000). Coloniality of power and Eurocentrism in Latin America. International Sociology, 15(2), 215-232.

Richardson, E. T., McGinnis, T., \& Frankfurter, R. (2019). Ebola and the narrative of mistrust. BMJ Global Health, 4(6). http://dx.doi.org/10.1136/bmjgh-2019-001932

Ritchie, L. M. P., Khan, S., Moore, J. E., Timmings, C., van Lettow, M., Vogel, J. P., Khan, D. N., Mbaruku, G., Mrisho, M., Mugerwa, K., \& Uka, S. (2016). Low-and middle-income countries face many common barriers to implementation of maternal health evidence products. Journal of clinical epidemiology, 76, 229-237.

Samb, O. M., Ridde, V., \& Queuille, L. (2013). Quelle pérennité pour les interventions pilotes de gratuité des soins au Burkina Faso?. Revue Tiers Monde, 3, 73-91.

Sarr, F. (2017). Écrire les humanités à partir de l'Afrique. In A. Mbembe \& F. Sarr (Eds.), Écrire l'Afrique-Monde (pp. 369-377). Dakar: Philippe Rey/Jimsaan.

Sarriot, E. G., Winch, P. J., Ryan, L. J., Edison, J., Bowie, J., Swedberg, E., \& Welch, R. (2004). Qualitative research to make practical sense of sustainability in primary health care projects implemented by non-governmental organizations. The International journal of health planning and management, 19(1), 3-22. 
Sekhon, M., Cartwright, M., \& Francis, J. J. (2017). Acceptability of healthcare interventions: an overview of reviews and development of a theoretical framework. BMC health services research, 17(1), 1-13.

Stein, S., Andreotti, V. D. O., \& Suša, R. (2019). 'Beyond 2015', within the modern/colonial global imaginary? Global development and higher education. Critical Studies in Education, 60(3), 281-301.

Sweeney, L. B., \& Meadows, D. (2010). The systems thinking playbook: Exercises to stretch and build learning and systems thinking capabilities. Chelsea Green Publishing.

Turshen, M. (2014). A global partnership for development and other unfulfilled promises of the millennium project. Third World Quarterly, 35(3), 345-357.

Vigan, A., Boyi, C., Dossou, J.-P., Gryseels, C., Kanhonou, L., \& Delvaux, T. (2020, November-December). Implication communautaire pour accélérer la réduction de la mortalité maternelle : données probantes pour des politiques plus appropriées au Bénin. [Poster presentation] Sixth Global Symposium on Health Systems Research (virtual symposium).

Wireko, I., \& Beland, D. (2017). Transnational actors and health care reform: Why international organizations initially opposed, and later supported, social health insurance in Ghana. International Journal of Social Welfare, 26(4), 405-415.

Whitfield, L. (2008). The politics of aid: African strategies for dealing with donors. Oxford University Press.

World Health Organization (WHO). (2015). Chapter 3. Factors that contributed to undetected spread of the Ebola virus and impeded rapid containment. In World Health Organization (pp. 4-10). Geneva: World Health Organization. http://www.who.int/entity/csr/disease/ebola/oneyear-report/factors/en/index.html 
Preprint version - Gautier et al., 2020

World Health Organization (WHO) Department of Reproductive Health and Research and Johns Hopkins Bloomberg School of Public Health/Center for Communication Programs (CCP) (2018). Family Planning: A Global Handbook for Providers (2018 update). Baltimore and Geneva: CCP and WHO. 
Preprint version - Gautier et al., 2020

Figure 1. The Iceberg Metaphor: a tool for guiding systemic thinking

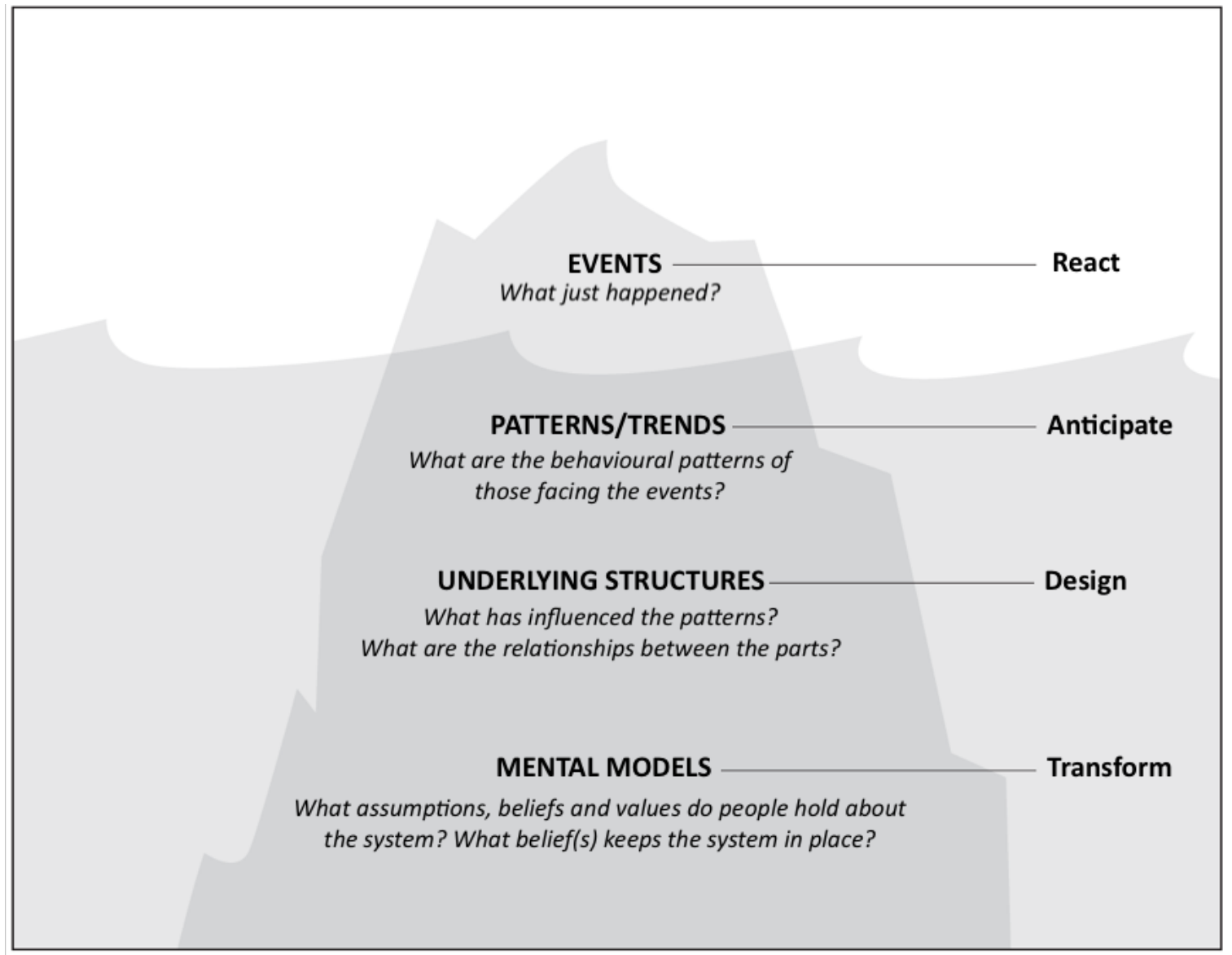

Source: Adapted from Sweeney \& Meadows, D. (2010) and

Ecochallenge dot org (https://ecochallenge.org/iceberg-model/). 